\title{
A New Low Protein Feeding Strategy for Enhancing Nitrogen Utilization in Lactating Dairy Cows
}

Soheila Ebrahimi, Seyed Hadi Ebrahimi*, Abbas Ali Naserian and Reza Valizadeh

Department of Animal Sciences, Faculty of Agriculture, Ferdowsi University of Mashhad, Mashhad, Khorasan Razavi, Iran

\begin{abstract}
This study assessed the impact of replacing soybean meal (SBM) with rapeseed meal (RSM) on the performance of lactating dairy cows with a focus on meals' potential for utilizable Crude Protein (UCP) supply at the duodenum. Four samples of SBM and two types of RSM were used in an in vitro experiment and the uCP of the samples was estimated. In the second experiment, nine Holstein dairy cows were used in a $3 \times 3$ Latin square design in which three experimental diets (differing in SBM to RSM ratio) were fed to the cows for the duration of 21 days. There was a significant difference in the effective uCP between treatments in all rate of passages $(p<0.001)$ and the effective UCP of pelleted RSM was significantly higher than the other protein meal samples. In case of soybean meals (except the outflow rate of $1 \%$ per hour), maximum and minimum of effective uCP were observed in one of the pelleted and powder SBMs, respectively. Dry matter intake, milk yield and compositions were not affected by the mentioned treatments. However, blood urea nitrogen was significantly greater $(p<0.01)$ in the cows fed only by SBM than other groups. Cows consumed RSM significantly excreted lower urinary nitrogen compare to animals fed with SBM $(p<0.01)$. Overall, lowering CP level in the diet of lactating dairy cows by using similar euCP supply from RSM as an alternative for SBM, decreased nitrogen losses with no influence on the animal performance.
\end{abstract}

Keywords: Utilizable crude protein; Plant protein meals; Nitrogen utilization; Dairy cow

\section{Introduction}

Soybean meal is imported in many countries and considered as strategic ingredient in feed industry hence, there has been the need to find alternative vegetal protein sources [1]. Rapeseed meal is one of the potential alternative protein sources for dairy cattle nutrition and allows formulating diets with lower feeding cost. Feeding canola meal (new varieties of rapeseed meal having low glocosinolate and erucic acid) as the major source of protein resulted an increase in milk yield and milk protein yield and a decrease in milk urea nitrogen [2]. Furthermore, canola meal reduced ruminal ammonia nitrogen $\left(\mathrm{NH}_{3}-\mathrm{N}\right)$ and branched-chain VFA concentrations [3]. Rapeseed meal has lower protein degradability compared to soybean meal [4] and Paula et al. [5] pointed out that positive production responses observed when SBM was replaced by canola meal, could be attributed to a better AA profile and post-ruminal effects and replacing SBM with canola meal has no major ruminal effects.

Commercial soybean meals which were originally different from the beans caused variety in the nutritive value and chemical composition of feeds [6]. Various oil extraction techniques as well as processing the produced meals may enhance these variations. Generally, meals are supplied in two physical forms (pelleted and powdered) in the market. Pelleted forms are preferred both by farmers and animal feed plants due to their lower transportation costs and lesser production of dust during the loading and unloading process and moreover, there are evidences which indicate that pelleting protein meals reduced the degradability of protein in the rumen [7]. Studying on the canola meal samples collected from Canadian processing plants over four years indicated that canola meals varied in RUP content [8] and this can influence metabolism of nitrogen in the rumen or/ and intestinal $\mathrm{N}$ utilization. Therefore, calculating RUP of TMR by NRC model may under or overestimate its value from the real quantity which estimated using in situ or in vitro methods [5]. In the current decade, a simple method has been developed by Edmunds et al. [9] for estimating utilizable Crude Protein ( $\mathrm{uCP}$ ) as the sum of the microbial crude protein and rumen undegradable protein. This method enables researchers to evaluate protein sources for their rumen degradability and microbial protein synthesis in $48 \mathrm{~h}$ without having to use the nylon bag technique and seems to be applicable for ration formulation.

In the studies where SBM was replaced with rapeseed or canola meals, greater proportion of rapeseed/canola meal were substituted in the ration to make isonitrogenous diets, which may economically have no value in terms of lowering feed expenditures. For instance $8.7 \% \mathrm{SBM}$ $(53.6 \% \mathrm{CP})$ was replaced by $11.4 \%$ of canola meal having $40.6 \% \mathrm{CP}$ [3] or $25 \%$ SBM replaced by $34.5 \%$ canola meal with CP content of 54.9 and $42.1 \%$, respectively [5]. Because RSM has lower rumen degradability than SBM [4], it could be possible to formulate diets having RSM with lesser protein content (but similar effective uCP) and by this strategy enhance $\mathrm{N}$ utilization efficiency in the animal. To test this hypothesis, we first studied the nature of the SBM and RSM samples in different physical forms as effective $\mathrm{uCP}$ at the duodenum using an in vitro technique. Moreover, the effect of similar effective uCP supply from the SBM, RSM and their combination on the production parameters of Holstein dairy cow was examined.

*Corresponding author: Dr. Seyed Hadi Ebrahimi, Assistant Professor, Department of Animal Sciences, Faculty of Agriculture, Ferdowsi University of Mashhad, Mashhad, Khorasan Razavi, Iran, Tel: +985138805744; E-mail: shebrahimi@um.ac.ir

Received February 04, 2018; Accepted March 16, 2018; Published March 19 2018

Citation: Ebrahimi S, Ebrahimi SH, Naserian AA, Valizadeh R (2018) A New Low Protein Feeding Strategy for Enhancing Nitrogen Utilization in Lactating Dairy Cows. J Vet Sci Technol 9: 523. doi: 10.4172/2157-7579.1000523

Copyright: (c) 2018 Ebrahimi S, et al. This is an open-access article distributed under the terms of the Creative Commons Attribution License, which permits unrestricted use, distribution, and reproduction in any medium, provided the original author and source are credited. 


\section{Materials and Methods}

\section{In vitro experiment}

Feed samples and chemical analysis: Overall, four samples of soybean meal (three in pellet form and one in the form of powder), and two samples of rapeseed meal (pellet and powder each) obtained from different commercial dairy farms during Jan-March 2016 (Table 1) were used in this experiment. Except one sample (soybean meal \# 4) which was produced in a local oil factory, the other samples were imported meals. All feed samples passed through a $1 \mathrm{~mm}$ screen in a Wiley mill (standard model 4: Arthur H. Thomas Co., Philadelphia, PA). Dry matter was measured after drying the samples for $48 \mathrm{~h}$ in an air-forced oven at a temperature of $65^{\circ} \mathrm{C}$. Ash content was determined after $3 \mathrm{~h}$ of incineration at $550^{\circ} \mathrm{C}$ in a muffle furnace and crude protein and ether extracts were estimated by standard method [10].

In vitro estimation of uCP: The experiments were performed according to the method described by Edmunds et al. [9]. The experiments were conducted at the Dairy Research Farm of the Faculty of Agriculture, Ferdowsi University of Mashhad (Iran) according to the guidelines presented by the Iranian Council of Animal Care. Rumen fluid for incubation was obtained $2 \mathrm{~h}$ prior to the morning feeding from two fistulated Holstein steers filtered through four layers of cheese cloths and mixed together at the same ratio immediately. Filtered rumen fluid was added to a buffered solution $(1: 2 \mathrm{v} / \mathrm{v})$ and it was retained in a water bath at $\approx 39^{\circ} \mathrm{C}$ under constant stirring and continuous flushing of $\mathrm{CO}_{2}$ to maintain its anaerobic conditions. The ground samples (200 mg, four replicates) were incubated for $8 \mathrm{~h}, 24 \mathrm{~h}$ and $48 \mathrm{~h}$, respectively, using $30 \mathrm{ml}$ of buffered rumen fluid in 120 serum bottles. For the corresponding correction of the uCP results between treatments, four bottles containing $200 \mathrm{mg}$ of ground concentrate with known $\mathrm{CP}$ and uCP (standard protein) were also included. Crude protein of the standard protein was $254 \mathrm{~g} / \mathrm{kg}$ and contained 232, 183 and $97 \mathrm{~g} / \mathrm{kg} \mathrm{uCP}$, for $8 \mathrm{~h}, 24 \mathrm{~h}$ and $48 \mathrm{~h}$, respectively. In addition, four bottles only containing the buffered rumen fluid (termed as blanks) were incubated for measuring ammonia nitrogen in the blank in each incubation time.

At the end of each incubation $(8,24$ and $48 \mathrm{~h})$, bottles were taken from water bath and chilled to $4^{\circ} \mathrm{C}$ in order to stop microbial activity. The Ammonia- $\mathrm{N}$ in the blanks and bottles containing substrate $\left(\mathrm{NH}_{3} \mathrm{~N}\right.$ sample) were measured by the distillation method [10] and used in the following equation:

$$
u C P(\mathrm{~g} / \mathrm{kgDM})=\frac{\mathrm{NH}_{3} N_{\text {blank }}+N_{\text {sample }}-\mathrm{NH}_{3} N_{\text {sample }}}{\text { weight }(\mathrm{mgDM})} \times 6.25 \times 1000
$$

Where $\mathrm{NH}_{3}-\mathrm{N}$ blank is the $\mathrm{NH}_{3}-\mathrm{N}$ amount of the blanks after incubation (mg), $\mathrm{N}$ sample is the $\mathrm{N}$ amount of the incubated sample (mg), $\mathrm{NH}_{3}-\mathrm{N}$ sample is the $\mathrm{NH}_{3}-\mathrm{N}$ amount of the sample contained in the bottles after incubation (mg) and weight is the total amount of sample on DM basis $(\mathrm{mg})$. Effective $\mathrm{uCP}$ values were calculated for passage rates of $0.02,0.04,0.06,0.08$ and $0.1 / \mathrm{h}$ through regressions of $\mathrm{uCP}$ values from $8 \mathrm{~h}, 24 \mathrm{~h}$ and $48 \mathrm{~h}$ of incubation against a log time (ln $(\mathrm{t})$ ) and calculated using the following formula:

$$
\text { effective } u C P=y+a \times \ln \left(\frac{1}{k_{p}}\right)
$$

Where $\mathrm{y}$, a and $k_{p}$ are the intercept, slope and passage rate, respectively.

\section{In vivo experiment}

Subjects, experimental design, and treatments: Using a $3 \times 3$ Latin square design, nine multiparous Holstein dairy cows (body weight [BW]: $570 \pm 15 \mathrm{~kg}$; days in milk [DIM]: $63 \pm 5$ ) were randomly assigned to three treatments. Each $21-\mathrm{d}$ period consisted of a 14-d diet adaptation followed by a 7-d sampling period. The selected cows were housed in individual tie-stalls during the experiment and had free access to water. The treatments included diet containing only rapeseed meal (RSM), diet containing only soybean meal (SBM), diet containing $6.5 \%$ rapeseed meal and $6.3 \%$ soybean meal (RSM+SBM). RSM and SBM refer to the numbered samples RSM1 and SBM3 in Table 1, respectively. The ingredients of the diets and chemical compositions are presented. Diets were formulated using NRC [11] model so as to contain equal levels of $\mathrm{NE}_{\mathrm{L}}$ and similar quantity of euCP $(k p=0.08 / \mathrm{h})$ supplied from SBM3, RSM1 or their combination. Cows were fed with equal portions of TMR twice a day at 09:00 and 21:00 h for ad libitum intake. The offered feed was adjusted daily to yield 5 to $10 \%$ orts.

Sampling and measurements: Feed intake was recorded daily for each dairy cow throughout the sampling period. The cows were milked at 07:00, 15:00, and 23:00 h, and the amount of milk yield was recorded for each milking. Milk samples were obtained on days six and seven of each period and stored at $4^{\circ} \mathrm{C}$ until later analyzed for identifying the milk components. During each sampling period, fecal samples were obtained from the rectum at 09:00 and 21:00 h and stored frozen at $-20^{\circ} \mathrm{C}$. At the end of the experimental periods, fecal samples of each cow were pooled and subsamples were taken for further analysis. Total urine output was collected in two plastic containers ( 20 liter) prepared for individual animal on days 1 and 2 of each period. Moreover, $900 \mathrm{ml}$ of $10 \% \mathrm{H}_{2} \mathrm{SO}_{4}$ was added to the container on a daily basis in order to protect the collected urine against bacterial destruction and prevention

\begin{tabular}{|c|c|c|c|c|c|c|}
\hline \multirow{2}{*}{ Item } & \multicolumn{4}{|c|}{ Treatments 1,2} \\
\cline { 2 - 6 } & SBM1 & SBM2 & SBM3 & SBM4 & RSM1 \\
\hline DM (\%) & $90.56 \pm 0.12$ & $91.01 \pm 0.20$ & $86.95 \pm 0.25$ & $90.55 \pm 0.07$ & $92.36 \pm 0.05$ \\
\hline OM (\%DM) & $92.35 \pm 0.18$ & $92.31 \pm 0.22$ & $93.19 \pm 0.01$ & $93.56 \pm 0.01$ & $92.85 \pm 0.35$ \\
\hline Ash (\%DM) & $7.64 \pm 0.18$ & $7.68 \pm 0.22$ & $6.80 \pm 0.01$ & $6.43 \pm 0.01$ & $7.41 \pm 0.35$ \\
\hline CP (\%DM) & $38.13 \pm 0.01$ & $40.09 \pm 0.15$ & $37.62 \pm 0.14$ & $32.06 \pm 0.03$ & $32.51 \pm 0.07$ \\
\hline EE (\%DM) & $3.40 \pm 0.11$ & $3.03 \pm 0.14$ & $3.43 \pm 0.18$ & $4.53 \pm 0.17$ & $30.32 \pm 0.05$ \\
\hline
\end{tabular}

DM: Dry matter; OM: Organic matter; CP: Crude protein; EE: Ether extract; SE: Standard error

${ }^{1}$ Mean \pm SE.

2SBM1: Pelleted Soybean meal 1; SBM2: Pelleted Soybean meal 2; SBM3: Pelleted Soybean meal 3; SBM4: Powder Soybean meal; RSM1: Pelleted Rapeseed meal; RSM2: Powder Rapeseed meal.

Table 1: Chemical composition of protein samples. 
of ammonia loss. Total urine output for the last $24 \mathrm{~h}$ was measured daily at 09:30 AM and an aliquot (1/500 of the total output) was taken for nitrogen estimation. On day four of each period, blood samples were taken from a jugular vein $2 \mathrm{~h}$ after the morning feeding. After coagulation, the samples were centrifuged at $3,000 \mathrm{rpm}$ for $15 \mathrm{~min}$ at $4^{\circ} \mathrm{C}$ and the serum was stored at $-20^{\circ} \mathrm{C}$ until it was analyzed. On the same day and after blood sampling, rumen liquor was obtained using stomach tube and the $\mathrm{pH}$ was immediately determined. Rumen liquor samples were then centrifuged at 3,000 rpm for $15 \mathrm{mins}$ and $10 \mathrm{ml}$ of supernatants were mixed with equal volume of $0.2 \mathrm{~N} \mathrm{HCl}$ and stored at $4^{\circ} \mathrm{C}$ for estimation of ammonia nitrogen.

Sample analysis and calculations: The dry matter of the samples was determined by drying them in an oven at $65^{\circ} \mathrm{C}$ for $48 \mathrm{~h}$. Dried feed and fecal samples were grounded to pass a $1 \mathrm{~mm}$ screen in a Willey mill (standard model 4; Arthur $\mathrm{H}$ Thomas Co., Philadelphia, PA) before analyses. Ash content and $\mathrm{CP}$ of the samples were determined as described earlier. Neutral detergent fiber (NDF) feeds and fecal samples were determined according to the procedure proposed by Van Soest et al. [12]. Acid insoluble ash was measured and used as an internal marker to determine the apparent total tract digestibility of nutrients. Total fecal excretion was calculated as described by Schneider and Flatt [13]. Milk samples were also analyzed for fat, crude protein, lactose, and SNF concentrations using Milko-Scan 605 analyzer (Foss Electric, Hillerød, Denmark). Moreover, blood samples were analyzed using an auto analyzer (Alcyon 300 i, Abbott, Abbott Park, IL).

Statistical models and analysis: Data of in vitro experiments were analyzed by a completely randomized design using GLM procedure of SAS (version 9.2; SAS Institute, Inc. Cary, NC, USA). The employed statistical model was as follows:

$$
\mathrm{Y}_{\mathrm{ij}}=\mu+\mathrm{T}_{\mathrm{i}}+\mathrm{e}_{\mathrm{ij}}
$$

where $Y_{i j}$ is the dependent variable, $\mu$ is the overall mean, $T_{i}$ is the effect of the physical form of the meal and $e_{i j}$ is the residual error. Orthogonal contrasts were constructed to evaluate the effect of: (1) SBM versus RSM and (2) pellet versus powder. A $3 \times 3$ replicated Latin square design was used for analyzing the in vivo experiment data by the MIXED procedure of SAS (version 9.2; SAS Institute, Inc. Cary, NC, USA). The model was as follows:

$$
\mathrm{Y}_{\mathrm{ijkl}}=\mu+\mathrm{S}_{\mathrm{i}}+\mathrm{C}_{\mathrm{j}(\mathrm{i})}+\mathrm{T}_{\mathrm{k}}+\mathrm{P}_{\mathrm{l}(\mathrm{i})}+\mathrm{e}_{\mathrm{ijk} \mathrm{kl}}
$$

where $Y_{i j k l}$ is the dependent variable, $\mu$ is the overall mean, $S_{i}$ is the random effect of square (1 to 3 ), $C_{j(i)}$ is the random effect of cow within square ( 1 to 3 ), $\mathrm{T}_{\mathrm{k}}$ is the fixed effect of treatments ( 1 to 3$), \mathrm{P}_{\mathrm{l}(\mathrm{j})}$ is the fixed effect of experimental period within square (1 to 3 ), and $e_{i j k \mathrm{l}}$ is the random residual error. In order to detect the difference between the means of dietary treatments, the least squares means procedure was declared at $\mathrm{P} \leq 0.05$ level, and trends were considered when $0.05<\mathrm{P} \leq$ 0.10 .

\section{Results}

\section{In vitro experiment}

The chemical composition of soybean and rapeseed meals is presented in Table 1. Crude protein content ranged from 30.32 in powder rapeseed meal to $40.09 \%$ in DM and was highest in the soybean meal sample \#2. Estimated uCP of the protein sources is summarized in Table 2. Significant differences were found between treatments with regards to $\mathrm{uCP}$ content at 8,24 and $48 \mathrm{~h}$ after the initiation of incubation $(\mathrm{p}<0.001)$. The $\mathrm{uCP}$ content of powder soybean meal (SBM4) was significantly higher than the other treatments, followed by pelleted rapeseed meal (RSM1) at the time $8 \mathrm{~h}$. Despite RSM1 supplied greatest amount of uCP at $24 \mathrm{~h}$ incubation $(159.51 \mathrm{~g} / \mathrm{kg} \mathrm{DM}), \mathrm{uCP}$ provided by SBM4 reduced to $35.95 \mathrm{~g} / \mathrm{kg} \mathrm{DM}$, which was the lowest quantity among all the treatments. The first, second and third rank for $\mathrm{uCP}$ at $48 \mathrm{~h}$ after the initiation of incubation belonged to RSM1, pellet soybean meal (SBM2), and powder rapeseed meal (RSM2), respectively (Table 2). Negative value for estimated uCP of SBM4 at $48 \mathrm{~h}$ indicated that no uCP could be provided by SBM4 at the above-mentioned in vitro incubation time, therefore biologically it means zero.

The estimated values for effective utilizable $\mathrm{CP}$ in the five passage rates are presented in Table 3 . As demonstrated, there was a significant difference in euCP between the treatments in outflow rates of $2-8 \%$ $(\mathrm{p}<0.001)$ and the effective $\mathrm{uCP}$ of RSM1 was significantly higher than the other treatments $(\mathrm{p}<0.05)$. Within soybean meals (except the outflow rate of $1 \%$ per hour), maximum and minimum of effective $\mathrm{uCP}$ were observed in SBM3 and SBM4, respectively (Table 4).

\section{In vivo experiment}

Feed Intake, apparent total-tract nutrient digestibility: The data with regard to nutrients intake and apparent total-tract nutrients digestibility are presented in Table 5. No significant differences were observed in the daily nutrients intake and apparent digestibility of DM, $\mathrm{OM}$ and $\mathrm{CP}$ among the three treatments.

Milk production and composition: Table 6 demonstrates the impact of feeding SBM and RSM alone or in combination on the amount of milk yield and composition. In the current study, the dietary treatments had no effect on milk fat, protein, lactose and solid-nonfat percentage and yields. Also, no differences were observed among the treatments with regards to the yield of ECM (3.5\%) and FCM (4\%).

Ruminal and blood metabolites: The data for ruminal and blood metabolites of cows fed treatments are presented in Table 7. There was

\begin{tabular}{|c|c|c|c|c|c|c|c|c|c|}
\hline \multirow{2}{*}{ Item } & \multicolumn{6}{|c|}{ Treatments $^{1}$} & \multirow[t]{2}{*}{ SEM } & \multicolumn{2}{|c|}{$p$-value ${ }^{2}$} \\
\hline & SBM1 & SBM2 & SBM3 & SBM4 & RSM1 & RSM2 & & Pellet vs powder & SBM vs RSM \\
\hline $\begin{array}{c}\mathrm{uCP} 8(\mathrm{~g} / \mathrm{kg} \\
\text { DM) }\end{array}$ & 226.84 & 229.66 & 240.06 & 267.12 & 242.12 & 218.2 & 1.88 & $>0.001$ & $>0.001$ \\
\hline $\begin{array}{c}\mathrm{uCP} 24(\mathrm{~g} / \mathrm{kg} \\
\text { DM) }\end{array}$ & 98.73 & 127.07 & 102.2 & 35.95 & 159.51 & 125.62 & 2.59 & $>0.001$ & $>0.001$ \\
\hline $\begin{array}{l}\text { uCP48 (g/kg } \\
\text { DM) }\end{array}$ & 39.57 & 93.74 & 55.56 & -35.21 & 103.88 & 86.09 & 13.9 & $>0.001$ & $>0.001$ \\
\hline
\end{tabular}
not a significant difference among the experimental treatments with

SEM: Standard error of the mean; uCP: Utilizable crude protein

1SBM1: Pelleted Soybean meal 1; SBM2: Pelleted Soybean meal 2; SBM3: Pelleted Soybean meal 3; SBM4: Powder Soybean meal; RSM1: Pelleted Rapeseed meal; RSM2: Powder Rapeseed meal.

${ }^{2}$ Orthogonal contrasts were constructed to evaluate the effect of: (1) pellet versus powder and (2) SBM versus RSM.

Table 2: Utilizable Crude Protein (uCP, g/kg DM) of the meals at 8 (uCP8), 24 (uCP24) and 48 (uCP48) h after starting incubation. 
Citation: Ebrahimi S, Ebrahimi SH, Naserian AA, Valizadeh R (2018) A New Low Protein Feeding Strategy for Enhancing Nitrogen Utilization in Lactating Dairy Cows. J Vet Sci Technol 9: 523. doi: 10.4172/2157-7579.1000523

Page 4 of 8

\begin{tabular}{|c|c|c|c|c|c|c|c|c|c|}
\hline \multirow{2}{*}{ Item } & \multicolumn{6}{|c|}{ Treatments $^{1}$} & \multirow{2}{*}{ SEM } & \multicolumn{2}{|c|}{ p-value ${ }^{2}$} \\
\hline & SBM1 & SBM2 & SBM3 & SBM4 & RSM1 & RSM2 & & Pellet vs powder & SBM vs RSM \\
\hline $\operatorname{EuCP}(k p=0.02 / h)$ & 29.91 & 82.84 & 41.32 & -85.98 & 101.6 & 78.38 & 2.24 & $>0.001$ & $>0.001$ \\
\hline EuCP $(k p=0.04 / h)$ & 103.12 & 136.52 & 114.12 & 45.1 & 154.96 & 130.16 & 1.33 & $>0.001$ & $>0.001$ \\
\hline EuCP $(k p=0.06 / h)$ & 145.95 & 167.93 & 156.7 & 121.78 & 186.17 & 160.44 & 1.18 & $>0.001$ & $>0.001$ \\
\hline $\operatorname{EuCP}(k p=0.08 / h)$ & 176.33 & 190.21 & 186.91 & 176.19 & 208.32 & 181.93 & 1.34 & $>0.001$ & $>0.001$ \\
\hline EuCP $(k p=0.1 / h)$ & 199.9 & 207.5 & 210.35 & 218.39 & 225.49 & 198.6 & 1.58 & 0.1 & 0.04 \\
\hline
\end{tabular}

SEM, standard error of the mean; EuCP, effective utilizable crude protein at the duodenum; kp, passage rate (/h)

1SBM1: Pelleted Soybean meal 1; SBM2: Pelleted Soybean meal 2; SBM3: Pelleted Soybean meal 3; SBM4: Powder Soybean meal; RSM1: Pelleted Rapeseed meal;

RSM2: Powder Rapeseed meal. 'Orthogonal contrasts were constructed to evaluate the effect of: (1) pellet versus powder and (2) SBM versus RSM.

Table 3: Effective utilizable Crude Protein (euCP) at the duodenum of the meal samples.

\begin{tabular}{|c|c|c|c|}
\hline Items & $\mathrm{RSM}^{1}$ & SBM & RSM+SBM \\
\hline \multicolumn{4}{|l|}{ Ingredients, \% of DM } \\
\hline Alfalfa hay & 20 & 20 & 20 \\
\hline Corn silage & 19 & 19 & 19 \\
\hline Barley grain & 14 & 14 & 14 \\
\hline Corn grain & 14 & 14 & 14 \\
\hline Cotton seed & 5 & 5 & 5 \\
\hline Rapeseed meal & 11.2 & 0 & 6.5 \\
\hline Soybean meal & 0 & 12.5 & 5.7 \\
\hline Wheat bran & 8.8 & 7.5 & 7.2 \\
\hline Fish Meal & 5 & 5 & 5 \\
\hline Calcium soaps of fatty acids & 1 & 1 & 1 \\
\hline Sodium Bicarbonate & 0.6 & 0.6 & 0.6 \\
\hline Vitamin and mineral premix ${ }^{3}$ & 0.7 & 0.7 & 0.7 \\
\hline Limestone & 0.5 & 0.5 & 0.5 \\
\hline Salt & 0.2 & 0.2 & 0.2 \\
\hline \multicolumn{4}{|c|}{ Chemical composition (\% of DM) } \\
\hline DM (\% as fed) & 55.4 & 55.8 & 55.9 \\
\hline OM & 92.1 & 92.1 & 91.5 \\
\hline $\mathrm{CP}$ & 15.5 & 16.6 & 16.1 \\
\hline EE & 5.3 & 4.8 & 5 \\
\hline NDF & 33.2 & 32 & 32.6 \\
\hline ADF & 21.2 & 19.7 & 20.4 \\
\hline $\mathrm{NFC}^{2}$ & 41.1 & 41.9 & 41.7 \\
\hline $\mathrm{NE}_{\mathrm{L}}^{3}(\mathrm{Mcal} / \mathrm{kg} \mathrm{DM})$ & 1.58 & 1.58 & 1.58 \\
\hline
\end{tabular}

DM: Dry matter; OM: Organic matter; CP: Crude protein; EE: Ether extract; NDF: Neutral detergent fiber; ADF: Acid detergent fiber; NFC: Non-fiber carbohydrate; NE ${ }_{L}$ Net energy for lactation.

${ }^{1}$ RSM: Diet containing only Rapeseed Meal; SBM: Diet containing only Soybean Meal; RSM+SBM: Diet containing 6.5\% Rapeseed Meal and 6.3\% Soybean Meal. RSM and SBM refer to RSM1 and SBM3 in table 4, respectively.

${ }^{2} \mathrm{NFC}=100-(\% \mathrm{NDF}+\% \mathrm{CP}+\%$ fat $+\%$ ash $)+\mathrm{NDIN} \times 6.25$ according to NRC.

${ }^{3}$ Estimated using the NRC (2001) model.

Table 4: Ingredients and chemical composition of experimental diets.

\begin{tabular}{|c|c|c|c|c|c|}
\hline \multirow{2}{*}{ Item } & \multicolumn{3}{|c|}{ Treatments $^{1}$} & \multirow{2}{*}{ SEM } & \multirow{2}{*}{ p-value } \\
\hline & RSM & SBM & RSM+SBM & & \\
\hline \multicolumn{6}{|l|}{ Feed Intake (kg/day) } \\
\hline Dry Matter & 20.94 & 20.33 & 20.7 & 0.57 & 0.57 \\
\hline Organic Matter & 18.98 & 18.56 & 18.98 & 0.27 & 0.25 \\
\hline Crude Protein & 3.24 & 3.37 & 3.25 & 0.13 & 0.21 \\
\hline $\mathrm{EuCP}^{2}$ (RSM, SBM or RSM+SBM) & 0.488 & 0.475 & 0.489 & 0.15 & 0.28 \\
\hline
\end{tabular}


Citation: Ebrahimi S, Ebrahimi SH, Naserian AA, Valizadeh R (2018) A New Low Protein Feeding Strategy for Enhancing Nitrogen Utilization in Lactating Dairy Cows. J Vet Sci Technol 9: 523. doi: 10.4172/2157-7579.1000523

Page 5 of 8

Apparent nutrient digestibility $(\%)$

\begin{tabular}{|c|c|c|c|c|c|}
\hline Dry Matter & 69.88 & 70.27 & 68.03 & 1.11 & 0.13 \\
\hline Organic Matter & 71.28 & 72.68 & 70.63 & 1.57 & 0.43 \\
\hline Crude Protein & 63.01 & 64.8 & 63.7 & 1.84 & 0.34 \\
\hline Neutral Detergent Fiber & 56.07 & 55.38 & 55.56 & 1.52 & 0.89 \\
\hline
\end{tabular}

SEM: Standard error of the mean; EuCP: Effective utilizable crude protein at the duodenum.

${ }^{1} \mathrm{RSM}$ : Diet containing only Rapeseed Meal; SBM: Diet containing only Soybean Meal; RSM+SBM, Diet containing 6.5\% Rapeseed Meal and 6.3\% Soybean Meal. RSM and SBM refer to RSM1 and SBM3 in table 4, respectively.

${ }^{2} \mathrm{EuCP}$ (RSM, SBM or RSM+SBM): Calculated euCP provided from RSM, SBM or both at an assumed passage rate of $0.08 / \mathrm{h}$.

Table 5: Effects of treatments on nutrient intake and apparent total tract digestibility.

\begin{tabular}{|c|c|c|c|c|c|}
\hline \multirow{2}{*}{ Item } & \multicolumn{3}{|c|}{ Treatments $^{1}$} & \multirow{2}{*}{ SEM } & \multirow{2}{*}{$p$-value } \\
\hline & RSM & SBM & RSM+SBM & & \\
\hline Milk Yield (kg/day) & 36.44 & 36.93 & 36.77 & 0.87 & 0.85 \\
\hline $4 \% \mathrm{FCM}^{2}$ (kg/day) & 36.7 & 37.87 & 36.28 & 0.98 & 0.27 \\
\hline $3.5 \% \mathrm{FCM}^{3}$ (kg/day) & 39.68 & 40.94 & 39.22 & 1.06 & 0.27 \\
\hline $\mathrm{ECM}^{4}$ (kg/day) & 38.74 & 39.85 & 38.51 & 0.95 & 0.35 \\
\hline Fat yield (kg/day) & 1.47 & 1.54 & 1.43 & 0.05 & 0.25 \\
\hline Protein yield (kg/day) & 1.1 & 1.12 & 1.12 & 0.02 & 0.77 \\
\hline Lactose yield (kg/day) & 1.65 & 1.68 & 1.68 & 0.04 & 0.83 \\
\hline SNF yield (kg/day) & 3.09 & 3.14 & 3.15 & 0.08 & 0.78 \\
\hline \multicolumn{6}{|c|}{ Composition } \\
\hline Fat $(\%)$ & 4.01 & 4.17 & 3.94 & 0.17 & 0.39 \\
\hline Protein (\%) & 3.04 & 3.04 & 3.08 & 0.02 & 0.34 \\
\hline Lactose (\%) & 4.56 & 4.56 & 4.61 & 0.05 & 0.6 \\
\hline SNF (\%) & 8.51 & 8.52 & 8.61 & 0.07 & 0.36 \\
\hline
\end{tabular}

SEM: Standard error of the mean; FCM: Fat corrected milk; ECM: Energy corrected milk; SNF: Solids non fat of milk.

${ }^{1} \mathrm{RSM}$ : Diet containing only Rapeseed Meal; SBM: Diet containing only Soybean Meal; RSM+SBM: Diet containing 6.5\% Rapeseed Meal and 6.3\% Soybean Meal. RSM and SBM refer to RSM1 and SBM3 in table 4, respectively.

$24 \% \mathrm{FCM}=0.4 \times$ milk $(\mathrm{kg} / \mathrm{d})+15 \times$ fat $(\mathrm{kg} / \mathrm{d})$.

${ }^{3} 3.5 \% \mathrm{FCM}=0.4324 \times$ milk $(\mathrm{kg} / \mathrm{d})+16.216 \times$ fat $(\mathrm{kg} / \mathrm{d})$.

${ }^{4} \operatorname{ECM}(\mathrm{kg} / \mathrm{d})=0.3246 \times$ milk $(\mathrm{kg} / \mathrm{d})+12.96 \times$ fat $(\mathrm{kg} / \mathrm{d})+7.04 \times$ protein $(\mathrm{kg} / \mathrm{d})$.

Table 6: Effects of treatments on milk production and composition.

regards to their ruminal $\mathrm{pH}$, but ruminal ammonia-N was significantly lower for cows receiving the RSM diet than those fed with SBM and the combination of both $(\mathrm{P}<0.001)$. The blood albumin, triglyceride and total cholesterol concentrations were not affected by dietary treatments. Also, there were no significant differences in the blood LDL, HDL, BHB, NEFA and total protein concentrations for all the treatments. However, the blood concentration of glucose decreased when RSM was fed alone compared to the cows which consumed SBM or both of the meals $(\mathrm{P}=0.07)$. Concentration of BUN was significantly $(\mathrm{p}<0.01)$ lower in the blood samples of the cows fed with RSM.

Nitrogen metabolism: The impacts of treatments on $\mathrm{N}$ metabolism and efficiency are summarized in Table 8 . As shown, the treatments were not significantly different with regards to milk protein $\mathrm{N}$ and fecal
$\mathrm{N}$ excretion. The feeding of RSM instead of SBM significantly reduced $(\mathrm{P}<0.01)$ urine volume and urinary $\mathrm{N}$ excretion. Differences in the least square means of $\mathrm{N}$ retention and efficiency between treatments were not significant.

\section{Discussion}

\section{In vitro experiment}

As presented in Table 1, CP content of six samples varied between $30.32 \pm 0.05$ to $40.09 \pm 0.15$. However, the variation of substrates in the amount of uCP (Table 2) was much higher than CP. Table 3 demonstrates that $24 \mathrm{~h}$ after starting incubation, $49.05 \%$ of CP content in the RSM1 $(159.51 \mathrm{~g} / \mathrm{kg} \mathrm{DM})$ was estimated to be uCP. However, in the same time span, only $27.16 \%$ of SBM3 (102.20 g/ kg DM) was accounted as uCP. 
Citation: Ebrahimi S, Ebrahimi SH, Naserian AA, Valizadeh R (2018) A New Low Protein Feeding Strategy for Enhancing Nitrogen Utilization in Lactating Dairy Cows. J Vet Sci Technol 9: 523. doi: 10.4172/2157-7579.1000523

Page 6 of 8

\begin{tabular}{|c|c|c|c|c|c|}
\hline \multirow{2}{*}{ Item } & \multicolumn{3}{|c|}{ Treatments $^{1}$} & \multirow{2}{*}{ SEM } & \multirow{2}{*}{ p-value } \\
\hline & RSM & SBM & RSM+SBM & & \\
\hline \multicolumn{6}{|l|}{ Ruminal } \\
\hline $\mathrm{pH}$ & 6.29 & 6.14 & 6.19 & 0.11 & 0.4 \\
\hline NH3-N (mg/dL) & 18.29 & 21.12 & 21.61 & 0.36 & $>0.001$ \\
\hline \multicolumn{6}{|l|}{ Serum parameters } \\
\hline Albumin (g/dL) & 4.23 & 4.25 & 4.42 & 0.16 & 0.48 \\
\hline Glucose (mg/dL) & 62.88 & 66.77 & 67.55 & 1.98 & 0.07 \\
\hline Cholesterol (mg/dL) & 242.22 & 229.66 & 236.6 & 5.72 & 0.12 \\
\hline Triglycerides (mg/dL) & 8.66 & 9.22 & 7.44 & 1.28 & 0.39 \\
\hline LDL (mg/dL) & 65.66 & 62.55 & 63.66 & 1.79 & 0.24 \\
\hline $\mathrm{HDL}(\mathrm{mg} / \mathrm{dL})$ & 237.22 & 225.88 & 237.8 & 7.42 & 0.23 \\
\hline $\mathrm{BHB}(\mathrm{mmol} / \mathrm{L})$ & 0.52 & 0.49 & 0.55 & 0.04 & 0.44 \\
\hline NEFA (mmol/L) & 0.08 & 0.05 & 0.08 & 0.03 & 0.55 \\
\hline Total protein $(\mathrm{g} / \mathrm{dL})$ & 9.02 & 8.91 & 8.95 & 0.19 & 0.85 \\
\hline BUN (mg/dL) & 20.35 & 22.94 & 21.65 & 0.69 & 0.008 \\
\hline
\end{tabular}

SEM: Standard error of the mean; LDL: Low-density lipoprotein; HDL: High-density lipoprotein; BHB: B-hydroxybutyrate; NEFA: Non-esterified fatty acid; BUN: Blood urea nitrogen.

${ }^{1}$ RSM: Diet containing only Rapeseed Meal; SBM: Diet containing only Soybean Meal; RSM+SBM: Diet containing 6.5\% Rapeseed Meal and 6.3\% Soybean Meal. RSM and SBM refer to RSM1 and SBM3 in table 4, respectively.

Table 7: Effects of treatments on ruminal and blood metabolites.

\begin{tabular}{|c|c|c|c|c|c|}
\hline \multirow{2}{*}{ Item } & \multicolumn{3}{|c|}{ Treatments $^{1}$} & \multirow{2}{*}{ SEM } & \multirow{2}{*}{$p$-value } \\
\hline & RSM & SBM & RSM+SBM & & \\
\hline N Intake (g/day) & 518.4 & 539.2 & 520 & 21.32 & 0.12 \\
\hline Milk protein $\mathrm{N}^{2}$ (g/day) & 174.6 & 176.04 & 176.71 & 4.78 & 0.78 \\
\hline \multicolumn{6}{|l|}{ Urinary excretion } \\
\hline Urine volume (L/day) & 22.75 & 24.01 & 24.24 & 0.35 & 0 \\
\hline Urinary N (g/day) & 148.2 & 168.17 & 150.27 & 5.23 & 0.01 \\
\hline Fecal N (g/day) & 190.8 & 189.37 & 188.36 & 8.2 & 0.1 \\
\hline $\mathrm{N}$ retention (g/day) & 4.85 & 5.62 & 4.66 & 0.74 & 0.3 \\
\hline Milk N efficiency ${ }^{3}(\%)$ & 33.67 & 32.65 & 33.98 & 0.89 & 0.16 \\
\hline
\end{tabular}

SEM: Standard error of the mean.

${ }^{1}$ RSM: Diet containing only Rapeseed Meal; SBM: Diet containing only Soybean Meal; RSM+SBM: Diet containing 6.5\% Rapeseed Meal and 6.3\% Soybean Meal. RSM and SBM refer to RSM1 and SBM3 in table 4, respectively.

${ }^{2}$ Milk protein $\mathrm{N}=$ Milk protein yield/6.38.

${ }^{3}$ Milk $\mathrm{N}$ efficiency=milk $\mathrm{N} /$ feed $\mathrm{N}$, where milk $\mathrm{N}=(\mathrm{g}$ of milk protein/pen per day $) / 6.38$ and feed $\mathrm{N}=(\mathrm{g}$ of feed $\mathrm{CP} /$ pen per day $) / 6.25 \times 100$.

Table 8: Effects of treatments on nitrogen metabolism.

The amount of uCP depends on two factors: i) degradability of the protein and RUP content, ii) quantity of the microbial crude protein synthesis. Therefore, uCP can reflect the RUP content of substrate at a particular incubation time period and passage rate. As explained in the results section, effective $\mathrm{uCP}$ of pelleted RSM1 was greater than the other treatments and in the outflow rate of $0.1 \%$ per hour, $69.35 \%$ of crude protein pelleted rapeseed meal consisted of utilizable crude protein in the duodenum, which was significantly $(\mathrm{P}<0.001)$ greater compared to the powder form $(65.48 \%)$. This may be due to lower ruminal degradability and more bypass protein of RSM1 compared to the other substrates. Kamalak et al. [14] revealed that at three outflow rates (2 and 5,6\%), effective degradability of CP in SBM was greater than RSM. Likewise, Maxin et al. found the effective degradability for CM and SBM to be $47.5 \%$ and $58.5 \%$, respectively. Hedquist and Uden [15] also reported that the effective CP degradability of RSM was lower than SBM (44\% and 73\%, respectively).
Some studies have pointed out that increasing temperature and heating time depressed CP degradability in the rumen and increased RUP concentration [16,17]. However, Huang et al. [7] reported that pellet conditioning could not reduce the RDP amount of canola meal. Mjoun et al. [18] reported that RUP content was greater in expeller soybean compared to solvent-extracted soybean and extruded soybean meals. Borucki Castero et al. [19] also found that the effective degradability of solvent-extracted soybean meal was higher than expeller soybean meal. Vaga et al. [20] used the present in vitro technique for evaluating of the heat treated protein samples and they observed an increase in the euCP of the substrates by heat processing. Variability of protein degradability among canola meals as a consequence of seed variety or the processing method also is known $[8,21]$.

Although few samples of the two meals were investigated in the present study, it appears that there is variation in the CP and uCP of protein meals probably due to the following reasons: i) origin of 
the beans as mentioned recently by García-Rebollar et al. [6], ii) the method and technology used for oil extraction, iii) physical form of the meals (pellet or powder) iv) combination of the pre-mentioned causes.

\section{In vivo experiment}

Feed intake, apparent total-tract nutrient digestibility and milk production and composition: As presented in Table 4, cows in different groups were supposed to consume iso-energetic diets and apparently different $\mathrm{CP} \%$ with the lowest level in treatments having only RSM (15.5\%) however formulation was performed to supply similar quantity of euCP from SBM3, RSM1 and their mixture. Based on the values of CP for SBM3 and RSM1 presented in Table 1 and nutrient intake in Table 5, it could be concluded that during the experiment, the cows fed in different groups received similar quantity of euCP which besides energy likeness was a reason for the same performance of three groups. In a very recent study [22], euCPs of 34 TMR samples (previously used in the 8 in vivo omasal flow trials) were estimated using current in vitro technique. Excitingly, the ranking of the euCP in samples was same as it observed in vivo omasal $\mathrm{CP}$ flow studies which conforms above justification. Broderick et al. [3] reported that replacing equal SBM crude protein with crude protein from CM increased DMI, milk production and the true protein content of the milk. In contrast, Mazhari et al. [23] found that dry matter intake decreased when cows were fed by RSM (as opposed to SBM), whereas milk production was not significantly affected by the treatments. A meta-analysis by Huhtanen et al. [24] indicated that the responses of DMI and daily milk yield were higher in CM compared to SBM. However, Martineau et al. [2] reported that when SBM was replaced with $\mathrm{CM}$, milk protein yield responded positively, but milk yield and ECM did not increase significantly.

As described in the results section, of the substitution of SBM3 with RSM1 did not have a significant impact on total tract digestibility of nutrients. Zagorakis et al. [25] also found that feeding rapeseed meal compared to soybean meal did not have adverse impact on nutrients digestibility, but crude protein digestibility was higher in the animals fed by SBM compared to those who consumed RSM. Similarly, Waldern [26] revealed that CP digestibility in cows fed by rapeseed meal diet was lower than the cows fed by the SBM diet.

Ruminal and blood metabolites: Although ruminal $\mathrm{pH}$ was not significantly influenced by the treatments, ammonia- $\mathrm{N}$ reduced when dairy cows received RSM containing ration, which is in agreement with the findings of Broderick et al. [3] who similarly point to lower ruminal degradation and greater RUP amount of CM protein. In contrast Paula et al. [5] concluded that replacing SBM with canola meal had no major ruminal effects. In the current study, feeding RSM and SBM did not prove to have a significant effect on blood metabolites, but glucose concentration tended to decline in cows fed by $\mathrm{CM}$ alone. In line with the findings of this study, Stockdale [27] reported that plasma glucose concentration was lowest in the treated canola meal pellets. In contrast, Mazhari et al. [23] claimed that substitution of SBM with CM does not change the blood concentration of glucose in dairy cows. We observed in the current study that treatments had no effect on cholesterol and triglyceride concentration. However, Delbecchi et al. [28] observed that compared to the control diet, cholesterol and triglyceride levels were higher in the diet containing formaldehyde-protected canola seeds. Additional ruminal ammonia-N is absorbed through the rumen wall and transported by the blood to the liver, where it is converted to urea. Since the replacement of SBM with RSM reduced the ruminal concentration of ammonia- $\mathrm{N}$, it could be expected that BUN concentration would be reduced in the animals fed by RSM.
Nitrogen metabolism: Similar to the findings of this study presented in Table 8, Waldern [26] reported that feeding CM and SBM did not change milk $\mathrm{N}$ excretion of dairy cows. However, Broderick et al. [3] found that the milk urea $\mathrm{N}$ concentration reduces when SBM is replaced by CM in the diet. Urine volume reduced when RSM replaced SBM in the diet that is in agreement with the findings of Broderick et al. [3] which resulted lower nitrogen excretion through urine. Within rations based on alfalfa hay and maize silage as major sources of forage and soybean meals as main protein source, maximum performance was observed with $16.5 \% \mathrm{CP}$ with minimum $\mathrm{N}$ excretion compare to greater levels of CP [29]. Broderick et al. [3] reported that consuming the diets containing $\mathrm{CM}$ or SBM did not change $\mathrm{N}$ efficiency in lactating dairy cows. It can be concluded from the data presented in Table 8 that by decreasing urine volume and nitrogen excretion via that and probably greater urea recycled to the rumen, animals fed with low protein level having only RSM maintained milk protein content. In a recent paper that supports our conclusion [30] lactating dairy cows were fed with a low protein diet (14.9\%) and canola meal as sole protein source. They observed significantly lower nitrogen excretion through urine and faces compare to cows consumed diet with $17.5 \% \mathrm{CP}$ without negative effect on milk production.

The findings of the present study suggest that in addition to $\mathrm{CP}$ content of protein meals used in commercial dairy farms or feed plants, their potential for providing metabolizable protein for ruminant animal (even within a meal) may vary. This may cause under or over-estimation of the metabolizable protein supply for the animal. Quantity of the $\mathrm{uCP}$ which a feed or total mixed ration could supply at the duodenum might be considered as a good index for diet formulation and fulfilling the nutritional needs of dairy cows resulting less $\mathrm{N}$ excretion to the environment. Overall, using rapeseed meal as an alternative for SBM in the diet of lactating dairy cows on the basis of potential for supplying euCP in the iso-energetic diets without needing to equalize $\mathrm{CP}$ concentration, successfully decreased nitrogen losses with no influence on animal performance.

\section{Acknowledgements}

The present study was supported by Ferdowsi University of Mashhad, Iran.

\section{References}

1. Ciurescu G (2009) Efficiency of soybean meal replacement by rapeseed meal and/or canola seeds in commercial layer diets. Arch Zootech 12: 27-33.

2. Martineau R, Ouellet DR, Lapierre H (2013) Feeding canola meal to dairy cows A meta-analysis on lactational responses. J Dairy Sci 96: 1701-1714.

3. Broderick GA, Faciola AP, Armentano LE (2015) Replacing dietary soybean meal with canola meal improves production and efficiency of lactating dairy cows. J Dairy Sci 98: 5672-5687.

4. Maxin G, Ouellet DR, Lapierre H (2013) Ruminal degradability of dry matter crude protein, and amino acids in soybean meal, canola meal, corn, and wheat dried distillers grains. J Dairy Sci 96: 5151-5160.

5. Paula EM, Monteiro HF, Silva LG, Benedeti PDB, Daniel JLP, et al. (2017) Effects of replacing soybean meal with canola meal differing in rumenundegradable protein content on ruminal fermentation and gas production kinetics using 2 in vitro systems. J Dairy Sci 100: 5281-5292.

6. García-Rebollar P, Cámara L, Lázaro RP, Dapoza C, Pérez-Maldonado R, Mateos GG (2016) Influence of the origin of the beans on the chemical composition and nutritive value of commercial soybean meals. Anim Feed Sci Technol 221: 245-261

7. Huang X, Khan NA, Zhang X, Yu P (2015) Effects of canola meal pelle conditioning temperature and time on ruminal and intestinal digestion, hourly effective degradation ratio, and potential nitrogen to energy synchronization in dairy cows. J Dairy Sci 98: 8836-8845.

8. Broderick GA, Colombini S, Costa S, Karsli MA, Faciola AP (2016) Chemica 
Citation: Ebrahimi S, Ebrahimi SH, Naserian AA, Valizadeh R (2018) A New Low Protein Feeding Strategy for Enhancing Nitrogen Utilization in Lactating Dairy Cows. J Vet Sci Technol 9: 523. doi: 10.4172/2157-7579.1000523

and ruminal in vitro evaluation of Canadian canola meals produced over 4 years. J Dairy Sci 99: 7956-7970

9. Edmunds B, Südekum K-H, Spiekers H, Schuster M, Schwarz FJ (2012) Estimating utilisable crude protein at the duodenum, a precursor to metabolisable protein for ruminants, from forages using a modified gas test. Anim Feed Sci Technol 175: 106-113.

10. AOAC (2006) Official Methods of Analysis of AOAC International. 17th edn Arlington, VA: Association of Official Analytical Chemists.

11. NRC (2001) Nutrient Requirements of Dairy Cattle. 7th edn. Washington DC. National Academy of Sciences.

12. Van Soest PJ, Robertson JB, Lewis BA (2010) Methods for Dietary Fiber Neutral Detergent Fiber, and Nonstarch Polysaccharides in Relation to Anima Nutrition. J Dairy Sci 74: 3583-3597.

13. Schneider BH, Flatt WP (1975) The Evaluation of Feeds through Digestibility Experiments. University of Georgia Press, Athens.

14. Kamalak A, Canbolat O, Gurbuz Y, Ozay O (2005) In situ ruminal dry matte and crude protein degradability of plant- and animal-derived protein sources in Southern Turkey. Small Rumin Res 58: 135-141.

15. Hedqvist $H$, Udén $P(2016)$ Measurement of soluble protein degradation in the rumen. Anim Feed Sci Technol 126: 1-21.

16. Petit HV, Tremblay GF, Tremblay E, Nadeau P (2002) Ruminal biohydrogenation of fatty acids, protein degradability, and dry matter digestibility of flaxseed treated with different sugar and heat combinations. Can J Anim Sci 82: 241 250

17. Doiron K, Yu P, McKinnon JJ, Christensen DA (2009) Heat-induced protein structure and subfractions in relation to protein degradation kinetics and intestinal availability in dairy cattle. J Dairy Sci 92: 3319-3330.

18. Mjoun K, Kalscheur KF, Hippen AR, Schingoethe DJ (2010) Ruminal degradability and intestinal digestibility of protein and amino acids in soybean and corn distillers grains products. J Dairy Sci 93: 4144-4154.

19. Borucki Castro SI, Phillip LE, Lapierre H, Jardon PW, Berthiaume R (2007) Ruminal Degradability and Intestinal Digestibility of Protein and Amino Acids in Treated Soybean Meal Products. J Dairy Sci 90: 810-822.
20. Vaga M, Hetta M, Huhtanen P (2017) Effects of heat treatment on protein feeds evaluated in vitro by the method of estimating utilisable crude protein at the duodenum. J Anim Physiol Anim Nutr 101: 1259-1272.

21. Theodoridou K, Yu P (2013) Effect of processing conditions on the nutritive value of canola meal and presscake. Comparison of the yellow and brownseeded canola meal with the brown-seeded canola presscake. J Sci Food Agric 93: 1986-1995.

22. Gidlund H, Vaga M, Ahvenjärvi S, Rinne M, Ramin M, et al. (2018) Predicting omasal flow of nonammonia $\mathrm{N}$ and milk protein yield from in vitro-determined utilizable crude protein at the duodenum. J Dairy Sci 101: 1164-1176.

23. Mazhari M, Danesh Mesgaran M, Heravi Moussavi A (2009) Effect of diet containing a variety of Iranian rapeseed meal (SLM sp.) on high producing lactating Holstein cow responses. J Anim Vet Adv 8: 265-269.

24. Huhtanen P, Hetta M, Swensson C (2011) Evaluation of canola meal as a protein supplement for dairy cows: A review and a meta-analysis. Can J Anim Sci 91: 529-543.

25. Zagorakis K, Liamadis D, Milis C, Dotas V, Dotas D (2015) Nutrient digestibility and in situ degradability of alternatives to soybean meal protein sources for sheep. Small Rumin Res 124: 38-44.

26. Waldern DE (1973) Rapeseed Meal Versus Soybean Meal As The Only Protein Supplement For Lactating Cows Fed Corn Silage Roughage Rations. Can J Anim Sci 53: 107-112.

27. Stockdale CR (2008) Effects of body condition score at calving and feeding various types of concentrate supplements to grazing dairy cows on early lactation performance. Livest Sci 116: 191-202.

28. Delbecchi L, Ahnadi CE, Kennelly JJ, Lacasse P (2001) Milk Fatty Acid Composition and Mammary Lipid Metabolism in Holstein Cows Fed Protected or Unprotected Canola Seeds. J Dairy Sci 84: 1375-1381.

29. Colmenero JJO, Broderick GA (2006) Effect of Dietary Crude Protein Concentration on Milk Production and Nitrogen Utilization in Lactating Dairy Cows. J Dairy Sci 89: 1704-1712.

30. Mutsvangwa T, Davies KL, McKinnon JJ, Christensen DA (2016) Effects of dietary crude protein and rumen-degradable protein concentrations on urea recycling, nitrogen balance, omasal nutrient flow, and milk production in dairy cows. J Dairy Sci 99: 6298-6310. 